\title{
PREMARITAL OF PRIVATE EDUCATION IN KANTOR URUSAN AGAMA (KUA) SEMARANG DISTRICT
}

\author{
Amat Mulyoko \\ Headman of KUA Semarang Regency \\ E-Mail: ahmatmulyoko@gmail.com
}

\begin{abstract}
Guidance of adolescent before marriage is carried out by Islamic Religious Instructor, Head and KUA Head. Islamic religious leaders guide mosque adolescents, prayer rooms and teaching assembly through routine or weekly teaching activities. The headman and head of the KUA carry out coaching for the bride and groom before the marriage ceremony. The lack of funds received by the KUA resulted in the implementation of the bride and groom course which caused the implementation to be not carried out to all prospective brides and responded by the KUA of Semarang regency through the private coaching of the bride and groom who wanted to carry out the wedding. This research is a qualitative analytic research and is a type of field research. Primary data sources, namely data obtained from interviews with the Office of the Ministry of Religion in Semarang, KUA in all districts of Semarang, and participants in premarital sex education, and secondary data in the form of books on marriage. Data collection methods are done by interview, documentation, and observation.
\end{abstract}

Keywords: education, premarital, teaching.

\section{INTRODUCTIONS}

According to Dr. Sudibyo Alimoso MA, Deputy KSPK BKKBN, The high divorce data in Indonesia is a serious matter because the family is the first education to lay the foundations of children's personality, ethics, and morals. Every person who wants to get married must reorganize the intention of the marriage they have, which is to make it a place of worship to God and a means to live in harmony or to understand one another to become a happy family. "Data of the Religious Courts (Badilag) of the Supreme Court of the Republic of Indonesia in 2010 reported that during 2005 to 2010, on average one in 10 married couples ended in divorce in court,". This means that there are two million married couples, and 285,184 couples divorced in 2010. That is the highest divorce rate in Indonesia as well as the highest in the Asia Pacific. The data, he continued, also showed that 70 percent of divorce was due to divorce from the wife on the grounds of being out of harmony. ${ }^{1}$

Based on data on marriage, divorce, divorce, and reconciliation at the Office of the Ministry of Religion in Semarang, data were obtained that in 2015 there were 7,696 pairs of marriage and divorce divorced totaling 1,796 pairs. The data can be concluded that divorce in Semarang Regency in 2015 reached 23 percent of the number of marriages.

Education is an effort to teach, raise awareness and information about sexual problems given to children, to keep children free from un-Islamic habits. ${ }^{2}$ Premarital education programs can provide solutions in terms of marriage satisfaction. ${ }^{3}$

1 Sudibyo Alimoeso, 'Angka Perceraian Di Indonesia Tertinggi Di Asia Pasifik’, 23 September 2013, 2013.

2 Moh Roqib, Ilmu Pendidikan Islam: Pengembangan Pendidikan Integratif Di Sekolah, Keluarga, Dan Masyarakat, Pertama (Yogyakarta: LKIS, 2009).

3 Mahdieh Yazdanpanah, Mohammad Eslami, and Nouzar Nakhaee, 'Effectiveness of the Premarital Education Programme in Iran', Hindawi Publishing Corporation, 2014 (2014), 5. 
While marriage or marriage is a physical and spiritual bond between a man and a woman as husband and wife to form a happy and eternal family based on the Godhead of the Almighty. ${ }^{4}$ While other opinions state that marriage in the view of Islam is something that is noble and sacred, worthy of worship to God, and the teachings of the Prophet based on sincerity, responsibility, and by legal provisions. $^{5}$

Marriage or marriage in the view of Islam has a noble goal of being a happy family according to the Koran. ${ }^{6}$ Research shows that marriage time is influenced by a person's demographic and family background. ${ }^{7}$ In general, women get married at a younger age when compared to men, ${ }^{8}$ it requires pre-marital education as education or knowledge for brides.

The Sub-District Religious Affairs Office (KUA) is the Ministry of Religion at the sub-district level whose tasks and functions are to carry out guidance, supervision and implementation and practice of religion. ${ }^{9}$ Regulation of the Minister of Religion number 517 of 2001 states that the KUA has the main duties and functions of marriage services, family guidance peaceful, social worship, preaching, and pilgrimage education (Director General of Islamic Community

4 Departemen Agama RI, Pedoman Pejabat Urusan Agama Islam (Jakarta: Dirjen Bimas Islam dan Penyelenggara Haji, 2004).

5 M Ridho Iskandar, 'Bimbingan Dan Konseling Islam Urgensi Bimbingan Pra Nikah Terhadap Tingkat Pencerian', JIGC (Journal of Islamic Guidance and Counseling), 2.Juni (2018), 63-78.

6 Munir Huda and others, 'Model Kurikulum Pendidikan Pra Nikah Untuk Membentuk Keluarga Sakinah: Studi Implementasi Surat Edaran Dirjen Bimas Islam Tentang Kursus Calon Penganten Di Kantor Urusan Agama Kabupaten Karawang', Turats, 12.1 (2016).

7 Jeremy E Uecker and Charles E Stokes, 'Early Marriage in the United States', NIH Public Acces, 70.4 (2010), 835-46 <https://doi.org/10.1111/j.17413737.2008.00530.x.Early>.

8 FK Goldscheider and LJ Waite, 'Sex Differences in the Entry into Marriage', American Journal of Sociology, 92 (1986), 91-109.

9 Departemen Agama RI
Guidance of the Ministry of Religion of the Republic of Indonesia, 2010). Peaceful family begins with the formation of the family through marriage, therefore marriage is highly recommended for those who have the ability. ${ }^{10}$ Islam teaches humans in choosing a partner should choose a pious partner, to achieve the goal of marriage is to form a peaceful family. ${ }^{11}$

Premarital education is guidance, teaching, awareness, and information about social ethics including sexual activity, sexual reproduction, age of marriage, reproductive health, a good time for reproduction, safe sex from disease, time suitable for childbirth and prohibition of sex according Islam and not having sexual relations before marriage. ${ }^{12}$

This phenomenon certainly makes people question how the role of KUA is currently related to the PMA. This paper will provide information and knowledge about the role of the Office of Religious Affairs (KUA) in all districts of Semarang in providing education to the community and the prospective bride and groom.

There are several previous studies such as Zulpiadi's Thesis entitled Pendidikan Seks Pada Remaja Menurut Islam, ${ }^{13}$ explains how to prevent free sex behavior of students and adolescents is to teach sex education according to Islam. The Islamic Education Curriculum (PAI) can be developed by integrating sex education materials according to Islam, with an emphasis on preventive rather than curative aspects.

10 Sulaiman Rasyid, Fiqih Islam (Bandung: Sinar Baru Algensindo, 2001).

11 Sayyid Sabiq, Fiqih Sunnah, Jilid 6 (Bandung: AlMa'arif, 1995).

12 Purnamansyah Bambang Sumardjoko, Sudarno Shobron, Muthoifin, 'Teacher Certification and Professionalism in Indonesia', International Journal of Advanced Science and Technology, 29.8 (2020), 64048.

13 Zulpiadi, 'Pendidikan Seks Pada Remaja Menurut Islam' (Universitas Islam Negeri (UIN) Syarif Hidayatullah, Jakarta: 2010, 2010). 
While Syaifuddin Zuhri and Herlina Model Pendidikan Seks (Sex Education) Orang TuaBagiRemaja GunaMencegah Seks Pranikah Serta Model Tayangan Alternatif Seksualitas. ${ }^{14}$ Explaining the motives of adolescents in seeking sexuality information due to the motives of increasing knowledge or seeking information due to curiosity or curiosity, motives for fostering relationships that are usually done with friends, entertainment motives (recreational sexuality), motives for seeking variation in lovemaking.

In contrast to Akhmad Alim Pendidikan Seks dalam Perspektif Tafsir Maudhu'i. ${ }^{15}$ Explaining sex education in the Qur'an is not only limited to physical orientation, but rather to the guidance of aqidah, worship, and life together in order to form the order harmonious society under the auspices of the syari'ah of God. Likewise, sex education in the Koran is not discriminatory as alleged by the bearers of gender ideology, but rather on the benefit of self-respect, guarding offspring and religion, as stipulated in the maqasidus syari'ah. ${ }^{16}$

While the Mutimatul Faidah Integrasi Pendidikan Seks dalam Kurikulum Pendidikan Agama Islam. ${ }^{17}$ explains the achievement of the success of sex education supported by three components that work together. The family is the first environment for adolescents to get nurture and instill moral values. The role of the family which is very strategic at the moment is experiencing a shift due to parents' ignorance of adolescent development, and parenting parents who

14 Syaifuddin Zuhri and Herlina, 'Model Pendidikan Seks (Sex Education) Orang Tua Bagi Remaja Guna Mencegah Seks Pranikah Serta Model Tayangan Alternatif Seksualitas', Ilmu-Ilmu Sosial, 8.April (2008).

15 Akhmad Alim, 'Pendidikan Seks Dalam Perspektif Tafsir Maudhu'i', At- Ta'dib, 9 (2014).

16 Muthoifin Sudarno Shobron, Amrin, Imron Rosyadi, 'Islamic Education Values in the Tradition of Peta Kapanca of Mbojo Community Tribe in West Nusa Tenggara', International Journal of Advanced Science and Technology, 29.5 (2020), 6802-12.

17 Mutimatul Faidah, 'Integrasi Pendidikan Seks Dalam Kurikulum Pendidikan Agama Islam",Tesis. IAIN Sunan' (IAIN Sunan Ampel, Surabaya, 2010). tend to be permissive. The impact of this shift, a home that is supposed to be a safe place for teenagers, becomes a comfortable place for some teenagers to channel their biological needs. Second, school. Sex education can be given in the teaching and learning process in the classroom by integrating it into PAI, as developed in this study or in other subjects. Third, society. Public awareness of the deviant behavior of adolescents can be in the form of social control of all elements of society, both religious leaders who act as cultural catalysts and community leaders and policymakers, namely the government. ${ }^{18}$

Some of the above researchers focused on the foundation and materials of sex education, while in this study the researchers tried to raise premarital education about the role of KUA for the community and the bride and groom before the wedding. The location of the difference in this research is the institution that is the object of research, the KUA, and the bride and groom before marriage, so from this problem the author intends to examine it as a thesis

\section{METHOD}

This research is a qualitative analytic research and is a type of field research. Primary data sources, namely data obtained from interviews with the Office of the Ministry of Religion in Semarang, KUA in all districts of Semarang, and participants in premarital sex education, and secondary data in the form of books on marriage. Data collection methods are done by interview, documentation, and observation. ${ }^{19}$

18 Agus Santoso Sudarno Shobron, Mutohharun Jinan, MA Fattah Santoso, Muthoifin, 'Contribution Boarding Schools For Social Changes In Central', International Journal of Psychosocial Rehabilitation, 24.06 (2020), 7851-59 <https://www.psychosocial.com/article/ PR260794/19358/>.

19 Sigit trihariyanto Muthoifin, Eko Supriyanto, 'PowerPoint as a Strategy and Media Learning to Improve the Quality of Islamic Education', International Journal of Advanced Science and 


\section{RESULTS AND DISCUSSION}

Premarital Education at KUA Semarang Regency. KUA is the implementing agency of the ministry of religion in the sub-district. KUA personnel consist of the Head of the KUA, Extension and general functional positions. In the implementation of coaching, it is divided into 1) Islamic religious instructors whose activities are to foster the teaching assembly, both children, adolescents, adults, and the general public, 2) the leader of the activities of fostering communityrelated to marriage. Whereas in this study the emphasis was on the head of the KUA and headman, who guided the community related to marriage.

This study uses data obtained from the Islamic Society Guidance Section of the Semarang Regency Ministry of Religion Office because head of the community guidance section (Kasi Bimas) is the coordinator of KUA in Semarang Regency and all daily activities of the Semarang Regency Religious Affairs Office are reported regularly and periodically.

All KUA heads plan to hold a bride to be course (suscatin) once a month, but the plan cannot go according to plan. 2017 is planned 12 times a year but practice can only be done once. This is certainly a reason why KUA cannot hold Suscatin every month,

Huda Muttaqin. MH said: "The interest of the bride and groom in participating in Suscatin is indeed extraordinary enthusiasm, but we regret that Suscatin cannot be carried out every month, this is because Suscatin is financed by the state from PNBPNR (Non-Marriage Tax Revenue State Revenue) whose disbursement follows MP or maximum disbursement from the minister. Finance of the Republic of Indonesia (Interview with Head of KUA Pringapus Huda Muttaqin, MH on 4 June 2018).

Technology, 29.7 (2020), 542-49.
Sutrisna, SH The Head of KUA of west Ungaran District hopes that the monthly subsidy fee can be disbursed every month so that the activities of KUA in all districts of Semarang can run smoothly and according to targets and plans, so that the KUA program can run according to plan. Meanwhile, the results of interviews with suscatin participants,

Umi Fadlilah, a Suscatin participant from west Ungaran District said: "Suscatin is very necessary for teenagers and brides, and we ask the KUA to hold a Suscatin holiday because the working day is that most prospective brides work to participate in these activities. need to take time off. "(Interview with former Suscatin participant, Umi Fadlilah on June 4, 2018)

In line with Umi Fadlilah, Suscatin participants from West Ungaran District Muhamad Syaiful Hadi from Pringapus hoped that the Suscatin would be held on holiday because of most teenagers and brides in the Pringapus district work as factory workers, which for factory employees is very difficult to permit including permits for suscatin.

Meanwhile, Muhammad Husain, a Suscatin participant from Bandungan Subdistrict, and Ambaryani, a Suscatin participant from Sumowono Subdistrict, was very thankful for having been included Suscatin, because more than 800 pairs of catin in Bandungan and Sumowono Subdistrict were included in Suscatin. (Interview with former Suscatin participant Umi Fadlilah) on June 5, 2018)

No matter how small the form that exists in an organization, it will certainly affect and harm the organization because the implementation of activities to achieve organizational goals will be hampered. Failing in achieving the goals set in the basics of organization.

Based on the data announcement called interview, there are several obstacles faced by the KUA of the District in carrying out Suscatin. According to 
Mr. Rowiyan Robby, SH. as the Head of Bandungan KUA: "There are several things that become the implementation of the KUA program, namely: First, the very limited budget that KUA has so that it cannot carry out activities including Suscatin every month, and the last is the very lack of Human Resources (HR) personnel who work in the Office of Religious Affairs (KUA).

The results of the analysis from the 4 districts as samples in this study each KUA head has a pattern and approach in delivering guidance to prospective brides, namely,

\section{Sumowono District}

The typology of the people of Sumowono Subdistrict is the average education of junior high school/ Madrasah Tsanawiyah and boarding school, the community is very protective of social ethics so that when young men and young women are seen often together by the parents of the daughters immediately married to avoid unwanted relationships, from this incident the majority of marriages in Sumowono is early marriage, is marriage less than 21 years old. The method used by the head of KUA in fostering them before marriage is emphasizing the education of children.

Bandungan District

As a community in a tourist area where education is needed to sustain life, in general, Bandungan people who get married in KUA have an average high school and MA education and many have a Bachelor's and even Master's education, and because of living in a tourist area many teenagers have already married before carrying out relationships before marriage. The pattern used by the head of Bandungan KUA (H. Rowiyyan Robby, $\mathrm{SH}$ ) in conducting premarital education is to instill religious education in the bride and groom and instill religious morals and invite them to pay attention to religious education in the next generation.

\section{Pringapus District}

As a livelihood in the industrial area is working in a factory, as well as teenagers in Pringapus District the average education is high school and after graduating high school directly work in the factory. The average age of marriage in the Industry region including Pringapus is over 21 years. The pattern of education adopted by the head of the KUA is a discussion with the bride and groom and the questions and answers.

West Ungaran District

The urban community certainly has a very complex problem, because in the city people gather with higher education and also low education, poor and rich, people who understand religion with no religion at all. The method applied by the head of KUA West Ungaran (Sutrisna, SH) for those with low education is guided and directed, for those with higher education, they are asked to discuss questions and answers and problem-solving.

Based on data that has been obtained from interviews with several parties, such as the head of the Office of Religious Affairs (KUA) District, head of the community guidance section (Kasi Bimas) Islam Semarang Ministry of Religion Office and former participants of Suscatin can be explained that KUA throughout Semarang Regency played a role in implementing premarital sex education through the bride and groom course (Suscatin), the implementation is planned every month, but the practice in 2017 was only carried out once and in 2018 until the end of June this research ended.

Guidance for bride and groom is pursued in 2 ways: private direct coaching for all brides by the head of the KUA during the examination and validation of marriage data and the bride and groom course, as well as the bride and groom course whose participants are taken by 60 pairs of bride and grooms each subdistrict. Early guidance conducted by KUA is by 
fostering youth education assembly by Islamic Religious Instructors, counseling is done once a week at the mosque and at the agreed place. ${ }^{20}$

\section{CONCLUSION}

Based on the results of prenuptial education research at KUA Semarang Regency in 2017-2018 there are three stages, namely planning, implementing and evaluating as.

In the planning stage, the KUA in all districts of Semarang has a plan to implement community development in the form of counseling and fostering Islamic youth and mosque youth carried out by Islamic Religious Instructors. At the beginning of each year, the head of the KUA in the sub-districts of Semarang makes a Suscatin plan which contains premarital education at KUA. The plan 20 Muthoifin, 'Shariah Hotel and Mission Religion in Surakarta Indonesia', Humanities and Social Sciences Reviews, 7.4 (2019), 973-79<https://doi.org/10.18510/ hssr.2019.74133>. contains the implementation time, place, estimated participants, material and tutors who will deliver the material.

In the implementation stage, premarital education carried out by Islamic Extension Workers is to provide regular counseling to mosque adolescents and Muslim youth through moral material and social ethics. While the head of the KUA and the headman provide the bride and groom after the wedding administration examination with a guide to the Muslim family about kinship and also held a sucatin about the implementation time, place, number of participants, material and tutors who have presented the material.

While at the final stage or evaluation to find out the achievements of the program carried out by Islamic Extension Workers, Head, and Head of KUA and the results of the evaluation are used to make plans for activities in the following year.

\section{REFERENCES}

Alim, Akhmad, 'Pendidikan Seks Dalam Perspektif Tafsir Maudhu'i', At-Ta'dib, 9 (2014)

Alimoeso, Sudibyo, 'Angka Perceraian Di Indonesia Tertinggi Di Asia Pasifik', 23 September 2013, 2013

Bambang Sumardjoko, Sudarno Shobron, Muthoifin, Purnamansyah, 'Teacher Certification and Professionalism in Indonesia', International Journal of Advanced Science and Technology, 29.8 (2020), 640-48

Departemen Agama RI, Pedoman Pejabat Urusan Agama Islam (Jakarta: Dirjen Bimas Islam dan Penyelenggara Haji, 2004)

Faidah, Mutimatul, 'Integrasi Pendidikan Seks Dalam Kurikulum Pendidikan Agama Islam", Tesis. IAIN Sunan' (IAIN Sunan Ampel, Surabaya, 2010)

Goldscheider, FK, and LJ Waite, 'Sex Differences in the Entry into Marriage', American Journal of Sociology, 92 (1986), 91-109

Huda, Munir, Didin Hafidhuddin, Ulil Amri Syafri, and Irfan Syauqy Beik, 'Model Kurikulum Pendidikan Pra Nikah Untuk Membentuk Keluarga Sakinah : Studi Implementasi Surat Edaran Dirjen Bimas Islam Tentang Kursus Calon Penganten Di Kantor Urusan Agama Kabupaten Karawang', Turats, 12.1 (2016)

Iskandar, M Ridho, 'Bimbingan Dan Konseling Islam Urgensi Bimbingan Pra Nikah Terhadap Tingkat Pencerian', JIGC (Journal of Islamic Guidance and Counseling), 
2.Juni (2018), 63-78

Muthoifin, Eko Supriyanto, Sigit trihariyanto, 'PowerPoint as a Strategy and Media Learning to Improve the Quality of Islamic Education', International Journal of Advanced Science and Technology, 29.7 (2020), 542-49

Muthoifin, 'Shariah Hotel and Mission Religion in Surakarta Indonesia', Humanities and Social Sciences Reviews, 7.4 (2019), 973-79 <https://doi.org/10.18510/ hssr.2019.74133>

Rasyid, Sulaiman, Fiqih Islam (Bandung: Sinar Baru Algensindo, 2001)

Roqib, Moh, Ilmu Pendidikan Islam: Pengembangan Pendidikan Integratif Di Sekolah, Keluarga, Dan Masyarakat, Pertama (Yogyakarta: LKIS, 2009)

Sabiq, Sayyid, Fiqih Sunnah, Jilid 6 (Bandung: Al-Ma'arif, 1995)

Sudarno Shobron, Amrin, Imron Rosyadi, Muthoifin, 'Islamic Education Values in the Tradition of Peta Kapanca of Mbojo Community Tribe in West Nusa Tenggara', International Journal of Advanced Science and Technology, 29.5 (2020), 6802-12

Sudarno Shobron, Mutohharun Jinan, MA Fattah Santoso, Muthoifin, Agus Santoso, 'Contribution Boarding Schools For Social Changes In Central', International Journal of Psychosocial Rehabilitation, 24.06 (2020), 7851-59<https://www. psychosocial.com/article/PR260794/19358/>

Uecker, Jeremy E, and Charles E Stokes, 'Early Marriage in the United States', NIH Public Acces, 70.4 (2010), 835-46<https://doi.org/10.1111/j.1741-3737.2008.00530.x.Early>

Yazdanpanah, Mahdieh, Mohammad Eslami, and Nouzar Nakhaee, 'Effectiveness of the Premarital Education Programme in Iran', Hindawi Publishing Corporation, 2014 (2014), 5

Zuhri, Syaifuddin, and Herlina, 'Model Pendidikan Seks (Sex Education) Orang Tua Bagi Remaja Guna Mencegah Seks Pranikah Serta Model Tayangan Alternatif Seksualitas', Ilmu-Ilmu Sosial, 8.April (2008)

Zulpiadi, 'Pendidikan Seks Pada Remaja Menurut Islam' (Universitas Islam Negeri (UIN) Syarif Hidayatullah, Jakarta: 2010, 2010) 